\title{
Edukacyjne aspekty działalności agroturystycznej w Polsce
}

\section{KEYWORDS}

ecology, young people, school education, extracurricular education, agritourism

\begin{abstract}
Wartecka-Ważyńska Agnieszka, Edukacyjne aspekty działalności agroturystycznej w Polsce [Educational aspects of agritourism business in Poland]. Kultura - Społeczeństwo Edukacja nr 2(14) 2018, Poznań 2018, pp. 245-258, Adam Mickiewicz University Press. ISSN 2300-0422. DOI 10.14746/kse.2018.14.17.
\end{abstract}

The paper addresses the problems of education, including environmental and cultural education, of children and young people offered by agritourism farms. The study also indicates the need for school education and extracurricular education of families involved in agritourism. Professional employees in agritourism represent precious human capital for rural areas and guarantee high quality of services, e.g. educational services for tourists, including children and young people. The particular focus was on education in the field of ecology and rural cultural heritage. Institutions in one way or another involved in education in agritourism were also discussed. The paper was written based on literature and results of empirical studies.

\section{Wstęp}

Agroturystyka, będąca jednym z rodzajów turystyki, związana jest z rolnictwem i oznacza pobyt turystów w czynnym gospodarstwie rolnym, gdzie produkcja rolna i hodowla zwierząt stanowią ważną atrakcję turystyczną. Nie bez znaczenia dla gości są inne walory środowiska wiejskiego, takie jak cisza i spokój, możliwość korzystania z zasobów naturalnych i dziedzictwa kulturowego wsi. Zainteresowanie agroturystyką w Polsce od kilkunastu lat szybko wzrasta, co powodowane 
jest zmianą upodobań oraz powrotem do starej, dobrej tradycji, popularnej już w XIX wieku, zwanej wyjazdami letniskowymi. Staje się ona też przedmiotem coraz szerszych zainteresowań naukowych w środowisku ekonomistów, socjologów, kulturoznawców, pedagogów (Stocki, 2000: 99). W świetle unijnej strategii wielofunkcyjnego rozwoju obszarów wiejskich przynosi znaczące efekty nie tylko ekonomiczne, lecz także społeczne, w tym edukacyjne.

Na edukacyjne aspekty agroturystyki zwraca właśnie uwagę niniejszy artykuł. Celem opracowania jest przedstawienie znaczenia edukacji szkolnej i pozaszkolnej świadczonej przez instytucje na rzecz osób zajmujących się tą działalnością. Wyedukowane kadry w agroturystyce to z jednej strony istotny kapitał ludzki wsi, a $\mathrm{z}$ drugiej gwarant wysokiego poziomu jakości świadczonych w tym zakresie usług. W artykule scharakteryzowano również samą działalność agroturystyczną prowadzoną w gospodarstwie rolnym, która ma szeroki wymiar edukacyjny, bowiem zaspakaja zróżnicowane potrzeby poznawcze turystów, szczególnie dzieci i młodzieży.

Podstawą napisania artykułu była analiza literatury przedmiotu, wyników badań ogólnopolskich prowadzonych przez instytucje rządowe oraz wniosków wypływających z badań własnych.

\section{Edukacyjny wymiar gospodarstwa agroturystycznego}

Turystyka pełni funkcję edukacyjną, gdyż pozwala turyście rozwijać zainteresowania poznawcze, rozszerzać jego wiedzę o kraju i świecie oraz zdobywać umiejętności właściwego spożytkowania tej wiedzy. „Kształceniowa funkcja turystyki może więc być spełniona zarówno w sensie poznawczym, jak i praktycznym. Turysta, zdobywając orientację w otaczającej go rzeczywistości przyrodniczej, społecznej i kulturowej, przyswaja sobie również pewne umiejętności oraz nawyki, które może spożytkować praktycznie" (Gaworecki, 2003: 395). Poznawanie dzięki agroturystyce środowiska przyrodniczego, kulturowego, społecznego wsi w drodze bezpośredniej obserwacji, doświadczenia, samokształcenia, jest formą weryfikacji wiedzy zdobytej w szkole, dzięki czytaniu książek, prasy, oglądaniu telewizji. Kształceniowa funkcja jest szczególnie istotna nie tylko dla młodzieży. Wymiar edukacyjny agroturystyki może interesować również innych turystów niezależnie od wieku, wykształcenia, różnic w potrzebach i zainteresowaniach oraz statusu społeczno-ekonomicznego.

Etapy życia człowieka można różnie klasyfikować, na przykład według wieku, założenia i stanu rodziny, tak zwanego wieku domowego. Każdy z nich 
charakteryzuje się innymi zainteresowaniami i możliwościami wyjazdów turystycznych. Specjaliści od turystyki zauważyli, iż większą rolę aniżeli wiek fizyczny odgrywa „wiek domowy” (domestic age). Uwzględniając to kryterium, wyróżnić można pięć podstawowych etapów w życiu człowieka (Sikorska-Wolak, 2007: 15), wpływających na decyzję i formę wyjazdów turystycznych na wieś:

1) dzieciństwo. Wyjazdy turystyczne odbywają się razem z rodzicami. Dopiero w 10-12 roku życia pojawiają się wyjazdy bez rodziców, najczęściej organizowane przez szkołę (np. „zielone szkoły”);

2) młodość. Okres potrzeby kontaktu z rówieśnikami, kształtowania się niezależności, potrzeby ciekawości świata; okres dużej ilości czasu wolnego, a zarazem natężonej aktywności turystycznej, determinowanej przeważnie możliwościami finansowymi. Gospodarstwa agroturystyczne stwarzają tanie warunki wypoczynku;

3) małżeństwo. Jest to okres stabilizacji życiowej, narodzin dzieci i realizacji życiowych planów. Inwestycje w mieszkanie, praca zawodowa, wychowywanie dzieci obniżają aktywność turystyczną skierowaną na długie i dalekie podróże. Alternatywą pozostają rodzinne wyjazdy do gospodarstwa agroturystycznego, które służą realizacji funkcji kształceniowo-wychowawczej całej rodziny oraz możliwości poświęcenia przez rodziców więcej czasu dzieciom i rodzinie;

4) etap „pustego gniazda”. Dorosłe dzieci opuszczają rodzinę; wyzwalają się od zależności finansowej i czasowej od rodziców, co wpływa na wzrost aktywności turystycznej jednych i drugich;

5) starość. Starsze osoby, tak zwanego „trzeciego wieku”, uwielbiają podróżować. Jednak polskich „emerytów” w aktywnym uczestnictwie w turystyce ogranicza bariera finansowa. Niemniej jednak ta grupa społeczna to obecni i potencjalni goście gospodarstw agroturystycznych, którym niejednokrotnie towarzyszą wnukowie. Wieś sprzyja wyjazdom turystycznym z dziećmi ze względu na duże wartości poznawcze i kształcące.

Gospodarstwa agroturystyczne i środowisko wiejskie mogą zaspokoić zróżnicowane potrzeby wszystkich wymienionych grup osób zainteresowanych wypoczynkiem na wsi. Stają się one pozaszkolnym miejscem edukacji w zakresie turystyki, rolnictwa, kultury ludowej, ekologii, ekonomii (Sikora, 2012: 232). W gospodarstwie agroturystycznym i okolicy można uprawiać aktywne oraz bierne formy turystyki i rekreacji (wycieczki piesze, rowerowe po okolicy, przejażdżki konne, wędkowanie, gra $\mathrm{w}$ piłkę, spacerowanie, zbieranie runa leśnego, zabawy i gry ruchowe na placu zabaw, pomoc przy czynnościach gospodarskich). 
Edukacyjna funkcja gospodarstwa agroturystycznego może uwzględniać wiedzę dotyczącą nowych kierunków hodowli, produkcji rolnej i ogrodniczej. Pozwoli zdobyć wiedzę i umiejętności z zakresu prac polowych, harmonogramu ich wykonywania, gatunków i odmian roślin uprawnych, gatunków i ras zwierząt inwentarskich, domowych, znajomości gatunków roślin ozdobnych, ozdobnych drzew i krzewów, sadzenia i pielęgnacji roślin.

Agroturystyka pozwala zaspokoić jedną z ważnych potrzeb człowieka, jaką jest potrzeba poznania. Pobyt na wsi, poznanie specyfiki życia i pracy w gospodarstwie agroturystycznym stwarza również możliwość poznania potencjału zasobów kulturowych wsi, społeczności lokalnej. Zapoznać się można z miejscową kulturą materialną w postaci architektury i budownictwa regionalnego (drewniane czy murowane chałupy, spichlerze, wiatraki, kościoły, dzwonnice, kapliczki, pałace i dwory, parki podworskie, folwarki); układów przestrzennych wsi, sposobów gospodarowania i wytwarzania tradycji rękodzielniczych, strojów, regionalnych potraw. Istotnym przykładem dziedzictwa kulturowego jest sfera kultury niematerialnej dotycząca wiary, obrzędów, zwyczajów, systemów wartości, która może ujawniać się w lokalnych świętach, odpustach, uroczystościach kościelnych, jarmarkach, w gwarze regionalnej.

Edukacyjna funkcja agroturystyki wyraża się również w tworzeniu warunków do poznania lokalnego dziedzictwa kulturowego poprzez organizację szlaków edukacyjnych opartych na bazie walorów kulturowych. Wieś kryje w sobie znaczący potencjał zasobów kulturowych, który należałoby zagospodarować i wypromować w taki sposób, aby zachęcić turystę do odkrywania, poznania tego, co mało znane i niedoceniane. Agroturystyka jest dla turysty nośnikiem wiedzy, a dla wsi i gospodarstwa agroturystycznego metodą na ocalenie dziedzictwa kulturowego od zapomnienia (Firlik, 2007: 208). Stwarza również możliwość porównania kultury właściwej w miejscu zamieszkania turystów z kulturą wiejską. Z jednej strony ukazuje odmienność tych kultur, a z drugiej uczy tolerancji i tworzy podstawę dialogu między nimi (Sikorska-Wolak, 2007: 18).

Przestrzeń wiejska, poza atrakcyjnym światem kultury, jest także istotnym światem przyrody, która stanowi jeden z elementów oferty agroturystycznej. Ważna jest zatem funkcja edukacyjna agroturystyki połączona z kształtowaniem świadomości ekologicznej społeczeństwa, nakazującej życie zgodne z prawami natury, zapobiegającej konsekwencjom nadmiernej eksploatacji zasobów przyrody. Korzystającym z niej można zwracać szczególną uwagę na problematykę stanu środowiska przyrodniczego i promowanie rozwoju turystyki zrównoważonej, która uwzględnia zasoby nie tylko przyrody, ale i społeczne (w tym kulturowe) i korzyści ekonomiczne. 
Gospodarstwo agroturystyczne nie tylko stwarza możliwości obcowania turysty z przyrodą, ale również może bezpośrednio wpływać na jej odnowę. Przykładem takim są programy „zielonych szkół”, dzięki którym istnieją możliwości przekazywania wiedzy o zasadach zachowania się w parkach krajobrazowych, narodowych, rezerwatach i obszarach chronionego krajobrazu; możliwości obserwacji we wszystkich porach dnia, nocy, roku różnych gatunków zwierząt i ich zachowań. $\mathrm{W}$ ich ramach tworzone są wszelkiego rodzaju przyrodnicze ścieżki dydaktyczne na terenie gospodarstwa lub w jego otoczeniu z przystankami w ogrodzie, na polu, w lesie, łące; włącza się turystów w prace przy zwierzętach gospodarskich; można uprawiać ogród metodami ekologicznymi. Edukacja w „zielonych szkołach" uwzględnia zachowanie dziedzictwa kulinarnego polegającego na wytwarzaniu produktów ekologicznych w gospodarstwie agroturystycznym.

Przykładem działalności edukacyjnej dzieci i młodzieży w ramach „zielonych szkół”, w której uczestniczą również lokalne stowarzyszenia agroturystyczne lub konkretne gospodarstwa agroturystyczne, organizowanej wspólnie z dyrekcją parków krajobrazowych, są liczne projekty przyrodnicze i edukacyjne. Między innymi w ostatnich latach w województwie kujawsko-pomorskim zrealizowano projekt pod nazwą „Utworzenie Ośrodka Edukacji Ekologicznej «Miętowy Gaj»”, który pełni funkcję „zielonej szkoły”. W województwie lubuskim skończony został projekt polsko-niemiecki pod nazwą „Młodzież kształtuje turystykę naturalną i edukację ekologiczną”. Projekt dotyczy Parku Narodowego „Ujście Warty”. W ramach działalności edukacyjnej przeprowadzane są warsztaty na terenie parku, podczas których dzieci i młodzież z polskich i niemieckich szkół poznają walory przyrodnicze, historyczne i kulturowe terenu. Projekt jest formą aktywizacji ekologicznej, poprzez czynny udział w kształtowaniu trasy wycieczek, ich opisu i promocji przy użyciu najnowszych technologii, między innymi urządzeń GPS. W województwie opolskim zrealizowany został projekt pn. „Wspieranie edukacji ekologicznej poprzez rozwój bazy edukacyjnej. Mobilne centrum edukacji ekologicznej”. W ramach projektu utworzona została objazdowa baza terenowa złożona $\mathrm{z}$ samochodu terenowego i przyczepy zamkniętej, wyposażonej w pomoce dydaktyczne do prowadzenia badań i obserwacji przyrodniczych i środowiskowych. Innowacyjność zajęć prowadzonych z jego wykorzystaniem polega na przemieszczaniu się w miejsca przyrodniczo ciekawe - warsztaty terenowe „pod chmurką”. W województwie wielkopolskim w starostwie powiatowym w Poznaniu realizowany jest program „Promocja ekologii poprzez edukację”, w ramach którego na terenie ośrodków edukacji przyrodniczej odbywają się fora wymiany doświadczeń ekologicznych. Uczestnikami spotkań są nauczyciele ze szkół powiatu poznańskiego, sołtysi, radni powiatowi, przedstawiciele gmin. 
Powyższe przykłady świadczą o tym, że na terenie całego kraju znajdują się ośrodki ekologiczne z bazą noclegową i edukacyjną, w których organizowane są między innymi plenery malarskie, warsztaty fotograficzne, rajdy, wycieczki, festyny. Działalność edukacyjna, z której każdego roku korzysta ponad 460 tys. dzieci i młodzieży, ma więc różnorodny i ciekawy charakter, stanowiąc atrakcyjną i uzupełniającą formę nauki w szkole (Haładkiewicz, 2014: 69).

Prowadzona $\mathrm{w}$ ten sposób edukacja ekologiczna, rozumiana jako psychologiczno-pedagogiczny proces oddziaływania na człowieka w celu kształtowania jego świadomości ekologicznej, towarzyszy turystyce edukacyjnej realizowanej również w gospodarstwach agroturystycznych (Wartecka-Ważyńska, 2010: 268). Obejmuje ona włączanie do programów szkół wszystkich szczebli tematyki z zakresu ochrony środowiska. Pojawia się w wielu przedmiotach i blokach przedmiotowych - zarówno w sformułowanych tam celach edukacyjnych, jak i zadaniach szkoły, treściach kształcenia i oczekiwanych osiągnięciach uczniów. Podstawowym zatem zadaniem całej społeczności szkolnej - dyrekcji, nauczycieli, uczniów i ich rodziców - winno stać się wyzwolenie i utrwalenie u uczniów potrzeby życia zgodnego z ideami zrównoważonego rozwoju (www.mos.gov.pl).

Wszystkie działania edukacyjne przyczyniają się do szerzenia i pogłębiania wiedzy o przyrodzie, rozwijają wrażliwość turysty i gospodarza oraz prowadzą do kształtowania świadomości ekologicznej, a tym samym wpisują się w nurt czynnej ochrony przyrody, przynosząc wymierne korzyści przyczyniające się do wzrostu i zachowania bioróżnorodności (Kurczewski, 2007: 256).

Edukacyjny wymiar agroturystyki wyraźnie zauważa się w kształtowaniu świadomości ekonomicznej rodziny prowadzącej gospodarstwo agroturystyczne, społeczności lokalnej, władz lokalnych, jak również samych agroturystów. Każdy uczestnik tej działalności agroturystycznej bezpośrednio i pośrednio osiąga korzyści ekonomiczne. Agroturysta ma korzyści, bo usługi agroturystyczne są tanie; społeczność lokalna może dodatkowo zarobić na turystach przebywających w ich miejscowości; samorząd lokalny uzyskuje korzyści dzięki zwiększonym podatkom płaconym przez biznes lokalny. Właściciel gospodarstwa agroturystycznego i jego rodzina również kalkulują opłacalność rozpoczęcia biznesu agroturystycznego (Sikora, 2012: 61).

Gospodarstwo agroturystyczne, pełniąc funkcję edukacyjną, kształtuje osobowościowy wizerunek gospodarza, o którym decydują takie cechy jak: wygląd zewnętrzny, cechy osobowościowe, wiedza, umiejętności, motywacje, zaangażowanie. Rolnik staje się osobą, która potrafi przekazać turyście własne doświadczenie, wiedzę, tradycję i współczesność płynącą z własnej pracy (Chojnacka-Ożga, Ożga, Kobiałka, 2007: 190). Kształtuje postawy mieszkańców wsi nacechowane życzli- 
wością, tolerancją, wyrozumiałością, otwartością, które pozwalają na tworzenie się bliższych więzi między turystami a lokalną społecznością.

Agroturystyka kształtuje wartości, które wyrażają również cele edukacyjne. Są to: ochrona środowiska przyrodniczego, ochrona materialnych zasobów kultury ludowej, rozpowszechnianie wartości kulturowych wsi, realizowanie zrównoważonej turystyki wiejskiej, szacunek oraz tolerancja wzajemna w kontaktach klientów i mieszkańców wsi. Szczegółowy wymiar powyższych wartości realizowanych przez gospodarstwo agroturystyczne zawiera tabela 1.

Tabela 1. Wartości edukacyjne gospodarstwa agroturystycznego

\begin{tabular}{|c|c|}
\hline Wartości edukacyjne & Komentarz \\
\hline Uczenie się przez działanie & $\begin{array}{l}\text { bezpośrednie doświadczenie poprzez działanie: obserwacja, dotyk, } \\
\text { próbowanie, samodzielne odkrywanie przyrody, produktów rolnych } \\
\text { i pracy rolnika. }\end{array}$ \\
\hline Uczenie się metod & $\begin{array}{l}\text { zdobywanie umiejętności polepszających ogólną sprawność proce- } \\
\text { sów uczenia się (zdolność obserwacji, analizowania, porównywania, } \\
\text { komunikowania, łączenia nowych wiadomości z posiadanymi, bu- } \\
\text { dowania wiedzy metodą indukcyjną). }\end{array}$ \\
\hline Przeżywanie emocji & $\begin{array}{l}\text { sytuacje, którym towarzyszą emocje (bliski kontakt ze zwierzętami, } \\
\text { zajęcia w otoczeniu przyrody) są dłużej pamiętane i kształtują oso- } \\
\text { bowość człowieka. }\end{array}$ \\
\hline $\begin{array}{l}\text { Uczenie się przebywania i pracy } \\
\text { w grupie }\end{array}$ & $\begin{array}{l}\text { rozwój umiejętności psychospołecznych i socjalizacji: przysposobie- } \\
\text { nia dzieci do przebywania i pracy w grupie - wspólne podejmowanie } \\
\text { decyzji, wzajemna współpraca, koordynacja działania. }\end{array}$ \\
\hline Bawienie się & $\begin{array}{l}\text { animacja dydaktyczna opiera się na zabawie, co stymuluje motywa- } \\
\text { cję do nauki i jest skutecznym sposobem na kształtowanie w dzie- } \\
\text { ciach zamiłowania do życia i pracy na wsi. }\end{array}$ \\
\hline Poznawanie i odkrywanie & $\begin{array}{l}\text { samodzielne poszukiwanie odpowiedzi na różne pytania (radość, } \\
\text { gdy udaje się je znaleźć); uważna obserwacja, stawianie pytań, po- } \\
\text { równywanie hipotez i wyjaśnień na temat życia roślin i zwierząt } \\
\text { z tym, co same widzą na wsi. }\end{array}$ \\
\hline Rozwijanie zmysłów & $\begin{array}{l}\text { oddziaływanie dźwięków, zapachów i smaków na zmysły dziecka, } \\
\text { rozwijanie zdolności percepcji sygnałów z otoczenia i umiejętności } \\
\text { rozpoznawania produktów żywnościowych. }\end{array}$ \\
\hline Rozwijanie zdolności ekspresji & $\begin{array}{l}\text { swoboda zajęć sprzyja wyrażaniu osobowości, rozwijaniu kreatyw- } \\
\text { ności i ekspresji, przede wszystkim dzięki pracom manualnym. }\end{array}$ \\
\hline Poznawanie kultury wsi & $\begin{array}{l}\text { poznawanie życia i pracy przeszłych pokoleń na wsi, wiejskich tra- } \\
\text { dycji i zwyczajów, przysłów biorących swój początek w mądrości } \\
\text { mieszkańców wsi. }\end{array}$ \\
\hline Zdobywanie doświadczenia & $\begin{array}{l}\text { zdobywanie wiedzy w otoczeniu zupełnie innym od sali lekcyjnej } \\
\text { poprzez doświadczenie. }\end{array}$ \\
\hline
\end{tabular}

Źródło: Chojnacka-Ożga, Ożga, Kobiałka, 2007: 190 
Wartości edukacyjne, które można realizować w gospodarstwie agroturystycznym na rzecz przebywających w nim dzieci i młodzieży, wskazują na naukę szacunku dla środowiska przyrodniczego i kulturowego wsi, poznanie pracy rolnika, naukę znajomości gatunków roślin i zwierząt, promocję wiedzy o zdrowych produktach żywnościowych (tab. 1). Edukacyjne aspekty gospodarstwa agroturystycznego powodują wzrost zainteresowania agroturystyką, a tym samym wymuszają potrzebę przygotowanej i wykształconej kadry agroturystycznej tworzonej przede wszystkim przez właściciela gospodarstwa i jego najbliższą rodzinę.

\section{Instyłucjonalny wymiar edukacji dla agroturystyki}

Działalność agroturystyczna wymusza odpowiednie przygotowanie rolników do tego rodzaju pracy i właściwą ich edukację. Przyjmowanie gości, wszechstronna ich obsługa, poznawanie zwyczajów, sposobu ubierania się, jakości dóbr konsumpcyjnych, sposobów spędzania czasu wolnego, wyzwala u usługodawców potrzebę kształcenia, uzupełniania poziomu wiedzy, nauki języków obcych (Marks, Jaszczak, Marks, 2007: 44). Kształcenie i doskonalenie zawodowe w zakresie agroturystyki, jak zaznaczono, prowadzone jest $\mathrm{w}$ dwóch grupach: przez system szkolnictwa średniego i wyższego, który przygotowuje kadrę z specjalistycznym wykształceniem zawodowym, oraz przez instytucje i stowarzyszenia, które przez prowadzone kursy i szkolenia nadają uprawnienia podstawowe lub uzupełniające, a także wiedzę $\mathrm{z}$ tej działalności.

Wśród instytucji i stowarzyszeń zajmujących się edukacją agroturystyczną zwrócić należy szczególną uwagę na ośrodki doradztwa rolniczego, które organizują różne kursy i szkolenia przeznaczone dla osób chcących podjąć prowadzenie działalności agroturystycznej. Edukacja ta obejmuje między innymi wiedzę z zakresu tworzenia produktu agroturystycznego, zdrowej żywności, marketingu, podstaw prawnych agroturystyki, tworzenia stron internetowych, opłacalności ekonomicznej i źródeł finansowania agroturystyki, języków obcych, osobowości usługodawcy, animacji czasu wolnego, obsługi klienta i jego potrzeb, przepisów sanitarno-higienicznych dotyczących gospodarstw wiejskich, estetyki zagrody wiejskiej, zasad i metod opodatkowania działalności agroturystycznej.

W zasadzie ośrodki doradztwa rolniczego były pierwszymi instytucjami, które propagowały ten rodzaj działalności na wsi. Stąd podstawowym celem pomocy rolnikom ze strony ośrodków doradztwa rolniczego jest edukacja i przekazywanie 
informacji. Wśród zadań informacyjno-doradczych, istotnych z punktu widzenia rozwoju agroturystyki, wymienić należy:

1) prowadzenie szkoleń dla rolników i innych mieszkańców wsi w zakresie rozwoju przedsiębiorczości na obszarach wiejskich;

2) promocję produktów lokalnych i regionalnych;

3) podejmowanie działań na rzecz zachowania dziedzictwa kulturowego i przyrodniczego wsi oraz ekologicznego i funkcjonalnego urządzania gospodarstwa rolnego;

4) promocję wsi jako atrakcyjnego miejsca wypoczynku;

5) prowadzenie szkoleń dotyczących ubiegania się o przyznanie pomocy finansowej lub współfinansowanej ze środków pochodzących z funduszy Unii Europejskiej (w tym na działalność agroturystyczną).

Do głównych form pomocy edukacyjno-doradczej należą kursy i szkolenia zarówno o charakterze przygotowującym, jak i doskonalącym. Wartość proponowanych form szkoleniowych dla właścicieli gospodarstw agroturystycznych polega nie tylko na poznaniu nowej wiedzy przekazywanej przez specjalistów, ale na możliwości wymiany doświadczeń między usługodawcami (Jachimowicz, Krzyżanowska, 2004: 83; Krzyżanowska, 2008).

Organizatorami działalności edukacyjnej w agroturystyce są także stowarzyszenia agroturystyczne. Ich członkowie nastawieni są na wymianę doświadczeń między sobą i współpracę informacyjną z innymi stowarzyszeniami. Z działalnością stowarzyszeń agroturystycznych rolnicy wiążą nadzieję na podniesienie kwalifikacji i dokształcanie się w zakresie obsługi ruchu turystycznego. Zajmują się głównie organizowaniem szkoleń dla swoich członków i osób zainteresowanych rozpoczęciem działalności agroturystycznej. Dokonują przeglądu gospodarstw agroturystycznych, przygotowują i wydają foldery, katalogi, uczestniczą w targach krajowych i zagranicznych, zajmują się reklamą w środkach masowego przekazu. Stowarzyszenia agroturystyczne stają się coraz liczniejszą i silniejszą formą organizacji pozarządowych działających na obszarach wiejskich.

W celu wzmocnienia funkcji szkoleniowej prowadzonej przez lokalne stowarzyszenia agroturystyczne powołana została Polska Federacja Turystyki Wiejskiej „Gospodarstwa Gościnne” (PFTW „GG”), która w sposób nieobligatoryjny zrzesza działające stowarzyszenia. Tematyka szkoleń prowadzonych przez PFTW „GG” jest różnorodna i dotyczy między innymi:

1) przepisów prawnych w agroturystyce;

2) znaczenia lokalnego dziedzictwa kulturowego w organizacji agroturystyki;

3) umiejętności komunikacji interpersonalnej;

4) pozyskiwania dodatkowych środków finansowych na rozwój agroturystyki; 
5) specyfiki świadczenia usług turystycznych na obszarach chronionych;

6) weryfikacji i szkolenia inspektorów ds. prowadzenia inspekcji kategoryzacji wiejskiej bazy noclegowej.

Edukację pozaszkolną w zakresie agroturystyki prowadzą również niektóre wojewódzkie izby rolnicze oraz firmy zajmujące się pozyskiwaniem funduszy unijnych. Terenem działania izby rolniczej jest obszar województwa. Do podstawowych jej zadań należą działania na rzecz rolnictwa, wpływanie na kształtowanie polityki rolnej, uczestniczenie w jej realizacji, a w szczególności doradztwo w zakresie działalności rolniczej, wiejskiego gospodarstwa domowego oraz uzyskiwania przez rolników dodatkowych dochodów (Walkowiak, 2004). Zadania izby rolniczej dotyczą również podejmowania działań na rzecz rozwoju infrastruktury rolnictwa i wsi oraz poprawy struktury agrarnej, podnoszenia kwalifikacji osób zatrudnionych w rolnictwie, kształtowania i upowszechniania zasad etyki i rzetelnego postępowania w dziedzinie gospodarczej, kształtowania świadomości ekologicznej producentów rolnych, działania na rzecz podnoszenia jakości środków i urządzeń stosowanych w działalności rolniczej oraz na rzecz poprawy warunków pracy $\mathrm{i}$ bezpieczeństwa $\mathrm{w}$ rolnictwie. Wszystkie zadania przypisane izbom rolniczym łączą się z działalnością agroturystyczną, która jednak w znikomym stopniu stanowi zainteresowanie tych instytucji.

Szeroki zakres zadań, które są w kompetencji izb rolniczych, w tym funkcje edukacyjne skierowane do rolników zajmujących się agroturystyką, nie są dobrze oceniane przez mieszkańców wsi. Świadczą o tym odpowiedzi na pytanie: „Jak ocenia Pan(i) pracę, działalność izb rolniczych z Pana(i) regionu?”, zawarte w ogólnopolskich badaniach na temat problemów wsi polskiej przeprowadzanych corocznie przez Ministerstwo Rolnictwa i Rozwoju Wsi. Z badań wynika, że tylko 19\% mieszkańców wsi pracę Izb Rolniczych ocenia bardzo dobrze i dobrze, 5\% źle i bardzo źle; natomiast aż $45 \%$ badanych nic nie wie o tym, żeby w ich regionie funkcjonowała izba rolnicza, a 31\% mieszkańców wsi nie miało zdania na temat pracy badanej instytucji (Polska wieś i rolnictwo 2013: 179). Można zatem zauważyć, że rola izb rolniczych w środowisku wiejskim jest bardzo słaba.

Agroturystyka znajduje również swoje miejsce w systemie edukacji szkolnej na poziomie średnim i wyższym. W ramach systemu szkolnictwa średniego realizowana jest $\mathrm{w}$ programach nauczania prowadzonych przez licea o profilu turystyczno-hotelarskim i rolniczym oraz przez różne szkoły policealne zarówno publiczne, jak i niepubliczne. Na poziomie szkolnictwa wyższego agroturystyka jako specjalność oraz jako przedmiot nauczania prowadzona jest $\mathrm{w}$ wielu ośrodkach dydaktycznych, również o charakterze publicznym i niepublicznym. Absolwenci opanowują wiadomości dotyczące podstaw produkcji rolniczej w zakresie prowa- 
dzenia wielokierunkowego gospodarstwa rolniczego i wykorzystują je w działalności agroturystycznej. Poznają zasady użytkowania roślin i zwierząt w agroturystyce i rekreacji, żywienia w gospodarstwach, pensjonatach i hotelach. Absolwenci są przygotowani do prowadzenia wszelkich działań związanych z planowaniem utworzenia gospodarstwa agroturystycznego i jego otoczenia. Podczas studiów zdobywają również wiedzę humanistyczną pozwalającą poznać potrzeby ludzkie oraz zrozumieć związki i procesy społeczne (Prochorowicz, 2007: 55). W ramach wiedzy humanistycznej nie bez znaczenia są problemy etyki w agroturystyce (Sikora, Wartecka-Ważyńska, 2015: 83).

Specjalność agroturystyka w programach studiów najszerzej prowadzona była na dawnych akademiach rolniczych, a obecnie na uniwersytetach przyrodniczych oraz innych uczelniach wyższych mających kierunki rolnicze, jak na przykład w zachodniopomorskim Uniwersytecie Technologicznym w Szczecinie, Szkole Głównej Gospodarstwa Wiejskiego w Warszawie, czy Uniwersytecie Warmińsko-Mazurskim w Olsztynie.

Niezależnie od edukacji formalnej, prowadzonej przez różnego typu szkoły średnie i wyższe oraz szkolenia na kursach organizowane przez powołane w tym celu instytucje, usługodawcy agroturystyczni mają możliwość aktualizacji i poszerzania swojej wiedzy w ramach samokształcenia, wykorzystując dostępną literaturę i zasoby internetowe. Przykładowo wśród stron internetowych zawierających informacje o samokształceniu w zakresie działalności agroturystycznej są strony: www.witrynawiejska.org.pl, www.agrinpol.pl, www.agroturystyka.pl, wbn.agroturystyka.pl, www.agroturystyka.edu.pl, www.zagrodaedukacyjna.pl (Pisarek, 2007: 102).

Podnoszenie kwalifikacji zawodowych osób związanych z działalnością agroturystyczną jest warunkiem koniecznym rozwoju tej działalności. Kapitał ludzki - w tym wykształcenie, wiedza, kwalifikacje - pozwalają dostrzegać jej pozytywne i negatywne strony, stymulować osiągane korzyści i ponoszone straty, a tym samym skuteczniej i efektywniej edukować rodziny prowadzące działalność agroturystyczną (Sikora, Wartecka-Ważyńska, 2009: 325).

Przedstawione instytucje administracji państwowej, samorządowej, prywatnej oraz organizacje pozarządowe wskazują na możliwość bezpośredniego lub pośredniego współdziałania edukacyjnego z gospodarstwami agroturystycznymi. Na współpracy tej dla obopólnych korzyści powinno zależeć jednej i drugiej stronie. W rozwój agroturystyki muszą być włączeni wszyscy partnerzy działający na regionalnym i lokalnym rynku. Regionalne i lokalne organizacje pozarządowe, samorządowe oraz społeczności lokalne, znając mocne i słabe strony agroturystyki, są w stanie szybciej i skuteczniej organizować i wspierać edukację na rzecz 
agroturystyki, a tym samym bardziej racjonalnie spożytkować wszelkie fundusze udostępniane $\mathrm{w}$ tym celu ze środków budżetowych i pozabudżetowych, $\mathrm{w}$ tym unijnych. Agroturystyka pozbawiona tego wsparcia nie jest w stanie, działając samodzielnie, zapewnić odpowiedniego standardu oferowanych usług.

Rolnicy, zdani tylko na siebie, sami sobie pomocy edukacyjnej nie zapewnią. Mają jednak możliwość wyboru instytucji do współdziałania. Stąd też należy zauważyć, iż edukacja w zakresie agroturystyki nie musi być jednoznacznie i wyłącznie zależna od stowarzyszeń agroturystycznych, ich federacji, od samorządu lokalnego, od ośrodków doradztwa rolniczego. Właściciele gospodarstw agroturystycznych mogą współpracować z izbami rolniczymi, z izbami turystycznymi oraz innymi organizacjami pozarządowymi. Dobrze jednak będzie, jeżeli lokalna aktywność edukacyjna rolników uwzględnia tradycje środowiska, funkcjonujące autorytety osobowe liderów wiejskich oraz wzbudza nadzieję mieszkańców wsi na osiągnięcie większych korzyści. Dobrze prosperujące gospodarstwa agroturystyczne inspirują do edukacji innych rolników, zachęcają do naśladowania oraz wprowadzania nowości pokrewnych agroturystyce. Brak przekonania do edukacji agroturystycznej w świadomości rolników wzmacnia postawę nieprzychylności, rodzi opory wobec agroturystyki.

\section{Podsumowanie}

Agroturystyka zaspokaja potrzeby poznawcze turystów, przede wszystkim dzieci i młodzieży przebywających na wsi. Działalność ta stanowi interesujący przykład edukacji turystycznej, kształtującej wartości ekonomiczne, ekologiczne i społeczne. Agroturystyka wymusza zatem odpowiednią wiedzę ze strony rolników. Rolnicy przyjmujący turystów muszą posiadać umiejętności z zakresu obsługi gości, sposobów organizowania wolnego czasu, promocji lokalnej kultury. Muszą uzupełniać poziom wiedzy z języków obcych. Powyższe potrzeby inspirują do rozwoju odpowiednich instytucji, które w swojej działalności edukacyjnej uwzględniają przedstawione zagadnienia.

\section{Literatura}

Chojnacka-Ożga L., Ożga W., Kobiałka W. (2007). Gospodarstwa dydaktyczne jako jedna z form działalności agroturystycznej na przykładzie włoskiej prowincji Mantui. [W:] I. Sikorska-Wolak (red.). Turystyka w rozwoju obszarów wiejskich. Warszawa. 
Firlik I. (2007). Kultura bogactwem turystyki wiejskiej, czyli o skarbach ukrytych w puszczy. [W:] J. Sikora (red.). Turystyka wiejska a edukacja. Różne poziomy, różne wymiary. Poznań.

Gaworecki W.W. (2003). Turystyka. Warszawa.

Haładkiewicz T. (2014). Informacja o działalności parków krajobrazowych na konwencie marszałków województw w Kielcach. „Biuletyn Parków Krajobrazowych Wielkopolski”, 20 (22).

Jachimowicz E., Krzyżanowska K. (2004). Pozarolnicze funkcje gospodarstwa rolniczego na przykładzie jego działalności agroturystycznej. Warszawa.

Karczewska M., Sikora J. (2005). Działalność lokalnych stowarzyszeń agroturystycznych w opinii kwaterodawców. „Turystyka wiejska a rozwój i współpraca regionów. Prace Naukowo-Dydaktyczne Państwowej Wyższej Szkoły Zawodowej w Krośnie" nr 15.

Krzyżanowska K. (2008). Komunikowanie w działalności przedsiębiorczej. Warszawa.

Kurczewski R. (2007). Edukacja ekologiczna w agroturystyce. [W:] J. Sikora (red.). Turystyka wiejska a edukacja. Różne poziomy, różne wymiary. Poznań.

Marks M., Jaszczak A., Marks E. (2007). Relacje między agroturystyką a edukacją środowiskową. [W:] J. Sikora (red.). Turystyka wiejska a edukacja. Różne poziomy, różne wymiary. Poznań.

Pisarek M. (2007). Wykorzystanie Internetu $w$ doskonaleniu zawodowym właścicieli gospodarstw agroturystycznych województwa podkarpackiego. [W:] J. Sikora (red.). Turystyka wiejska a edukacja. Różne poziomy, różne wymiary. Poznań.

Polska wieś i rolnictwo 2013. Prezentacja wyników badania. (2013). Ministerstwo Rolnictwa i Rozwoju Wsi. Warszawa.

Prochorowicz M. (2007). Formy edukacji w zakresie świadczenia i poprawy jakości usług turystycznych na wsi. [W:] J. Sikora (red.). Turystyka wiejska a edukacja. Różne poziomy, różne wymiary. Poznań.

Sikora J. (2012). Agroturystyka. Przedsiębiorczość na obszarach wiejskich. Warszawa.

Sikora J., Wartecka-Ważyńska A. (2009). Kapitał ludzki i kapitał społeczny czynnikiem rozwoju agroturystyki. [W:] B. Meyer, A. Panasiuk (red.). Wspótczesne problemy funkcjonowania gospodarki turystycznej. „Ekonomiczne Problemy Turystyki” nr 12. Szczecin.

Sikora J., Wartecka-Ważyńska A. (2015). Etyka w kształceniu kadr dla branży turystycznej. [W:] S. Bosiacki (red.). Kształcenie kadr dla gospodarki turystycznej i rekreacji. Stan obecny i prognozy. Poznań.

Sikorska-Wolak I. (2007). Turystyka jako system dydaktyczno-wychowawczy. [W:] J. Sikora (red.). Turystyka wiejska a edukacja. Różne poziomy, różne wymiary. Poznań.

Stocki A. (2000). Niektóre zagadnienia w zakresie edukacji związane z rozwojem agroturystyki. [W:] R. Gałecki, A. Gotowt-Jeziorska, W. Ruszniok (red.). Wychowanie dla turystyki. Wspomaganie uczestnictwa dzieci i młodzieży w turystyce. Warszawa.

Walkowiak K. (2004). Rola izb rolniczych w rozwoju wsi i rolnictwa w Polsce. Poznań.

Wartecka-Ważyńska A. (2010). Obszary przyrodniczo-chronione możliwościa rozwoju turystyki edukacyjnej. Studium przypadku ścieżki edukacyjnej, przyrodniczo-leśnej Kani Rudej. [W:] M. Jalinik (red.). Turystyka na obszarach przyrodniczo cennych. Białystok.

www.mos.gov.pl 
